\title{
ANALISIS FAKTOR-FAKTOR YANG MEMPENGARUHI PROFITABILITAS UNIT PENGELOLA KEGIATAN SIMPAN PINJAM PEREMPUAN (UPK SPP) DI LAMPUNG SELATAN
}

\author{
Maria Darmayanti P ${ }^{1}$, Suardi Tarumun ${ }^{2}$, dan Ahmad Rifai ${ }^{3}$ \\ Fakultas Pertanian Universitas Riau
}

\begin{abstract}
Abstrak
Penelitian ini bertujuan menganalisis faktor-faktor yang mempengaruhi profitabilitas Unit Pelaksana Kegiatan Simpan Pinjam Perempuan (UPK SPP). Penelitian ini dilakukan dengan metode survey pada 10 UPK SPP di Lampung Selatan yang ditentukan secara purposive dengan pertimbangan UPK SPP yang telah beroperasi dan telah menerbitkan laporan keuangan dengan lengkap berupa laporan neraca dan laporan laba rugi serta laporan jumlah peminjam pada tahun 2011 sampai 2015. Data yang digunakan adalah data Laporan Keuangan berupa neraca keuangan dan laporan rugi/laba. Metode penelitian yang digunakan dengan menganalisis rasio keuangan yang meliputi rasio likuiditas (Current Ratio/CR), rasio solvabilitas (Debt to Assets Ratio/DAR dan Primary Ratio/PR), dan analisis kinerja sosial yaitu Jumlah Peminjam (JP). Analisis regresi berganda dengan persamaan kuadrat terkecil (OLS) digunakan untuk menganalisis faktor-faktor yang mempengaruhi profitabilitas UPK-SPP. Hasil penelitian menunjukkan bahwa Current Ratio (CR), Debt to Assets Ratio (DAR), Primary Ratio (PR), dan Jumlah Peminjam (JP) secara bersama-sama mempengaruhi tingkat keuntungan (profitabilitas) dengan proxy indikator Return on Assets (ROA) UPK-SPP. Secara parsial, kinerja keuangan UPK-SPP Current Ratio (CR) dan Primary Ratio (PR) tidak berpengaruh secara signifikan terhadap tingkat profitabilitas (ROA) UPK-SPP. Tetapi kinerja sosial dengan indikator Jumlah Peminjam (JP) yang mempengaruhi tingkat profitabilitas (ROA) UPK-SPP secara parsial.

Kata kunci: Analisis Rasio Keuangan, Analisis Kinerja Sosial, Current Ratio (CR), Debt to Assets Ratio (DAR), Primary Ratio (PR), Jumlah Peminjam (JP), Return on Assets (ROA)
\end{abstract}

\section{PENDAHULUAN}

Indonesia merupakan negara dengan jumlah penduduk 261.115.456 jiwa (World Bank, 2016). Dari jumlah tersebut berdasarkan data Badan Pusat Statistik (September 2017) jumlah penduduk miskin Indonesia sebesar 26,58 juta jiwa (BPS, 2017). Hal ini menunjukkan bahwa kemiskinan merupakan salah satu masalah yang dihadapi oleh Indonesia. Untuk mengukur kemiskinan, Badan Pusat Statistik (BPS) menggunakan konsep kemampuan memenuhi kebutuhan dasar yang berarti ketidakmampuan dari sisi ekonomi untuk memenuhi kebutuhan dasar (Badan Pusat Statistik, 2017). Peraturan Presiden Nomor 15 tahun 2010 tentang Percepatan Penanggulangan kemiskinan berbasis pemberdayaan masyarakat, menegaskan bahwa penangulangan kemiskinan bertujuan 
untuk mengembangkan potensi dan memperkuat kapasitas kelompok masyarakat miskin untuk terlibat dalam pembangunan yang didasarkan pada prinsip-prinsip pemberdayaan masyarakat. Salah satu program penanggulangan kemiskinan yang dilakukan oleh Pemerintah Republik Indonesia antara lain Program Nasional Pemberdayaan Masyarakat Mandiri (PNPM Mandiri) yang termasuk Program Klaster II. Program ini memberikan perhatian yang lebih khusus terhadap perempuan dalam bentuk kegiatan Simpan Pinjam khusus Perempuan. Kegiatan Simpan Pinjam Perempuan dikelola oleh lembaga yang ada di kecamatan dengan nama Unit Pengelola Kegiatan (UPK).

Unit Pengelola Kegiatan yang terdapat di Kabupaten Lampung Selatan dimulai pada tahun 2007 sejak dimulainya Program Nasional Pemberdayaan Masyarakat Mandiri (PNPM Mandiri) Pedesaan. UPK Kecamatan yang berdiri pada tahun 2007 antara lain UPK Kecamatan Natar, UPK Kecamatan Jati Agung, UPK Kecamatan Tanjung Bintang dan UPK Kecamatan Sidomulyo. Sedangkan pada tahun 2008 berdiri UPK Kecamatan Palas. UPK Kecamatan Merbau Mataram, UPK Kecamatan Kalianda dan, UPK Kecamatan Rajabasa, UPK Kecamatan Way Sulan dan UPK Kecamatan Tanjung Sari berdiri pada tahun 2009. Pada akhir Desember 2014 Pemerintah mengakhiri Program PNPM yang dikelola oleh Kementerian Dalam Negeri dengan beralihnya wewenang kepada Kementerian Desa, Pembangunan Daerah Tertinggal dan Transmigrasi. Hal ini diperkuat berdasarkan Peraturan Presiden Nomor 12 Tahun 2015 tentang Kementerian Desa, Pembangunan Daerah Tertinggal dan Transmigrasi (Kemendesa-PDTT) yang menetapkan bahwa Kemendesa PDTT merupakan kementerian yang berwewenang untuk menyelenggarakan urusan pemerintahan di bidang pembangunan desa dan kawasan perdesaan, pemberdayaan masyarakat desa, percepatan pembangunan daerah tertinggal, dan transmigrasi. Berdasarkan wewenang tersebut maka pelaksanaan PNPM MPd dinyatakan berakhir.

Pada awalnya hal inilah yang menjadi dilema bagi UPK dalam mengelola kegiatannya karena belum ada aturan yang jelas mengenai tindak lanjut dari UPK SPP. Ada beberapa UPK yang tetap menjalankan kegiatan UPK SPP seperti semula dan ada yang mulai untuk melegalkan UPK SPP untuk menjadi Lembaga Keuangan Mikro sehingga mempunyai kekuatan hukum. Pengurus UPK SPP merasa bertanggung jawab atas dana yang telah diterima dan dana yang ada sudah menjadi dana masyarakat desa sendiri. Namun setelah keluarnya Mendes Nomor 5.074/M-DPDTT/02/2017 tertanggal 
6 Februari 2017 tentang Rekapitulasi Dana Perguliran dan Aset lain Pasca PNPM Mandiri Pedesaan sampai Desember 2016 maka UPK telah diberikan wewenang untuk tetap mengelola perguliran dana.

UPK SPP yang ada di Kabupaten Lampung Selatan perkembangannya sangat baik dan menurut data dari Laporan Pemetaan Bulanan Fasilitator Kabupaten Lampung Selatan (2014) semua UPK memiliki kategori A dilihat dari aspek Kuantitatif yang berarti UPK mempunyai pinjaman lebih dari 300 juta dan hasil pemetaan lebih dari 4. Hal ini menunjukkan bagaimana pengelolaan yang baik oleh pengurus UPK. Kegiatan Simpan Pinjam Perempuan ini sangat menolong bagi masyarakat miskin. Dana pinjaman ini dijadikan modal usaha oleh Kelompok berupa Usaha Ekonomi Produktif, sehingga warga desa terbantu dalam pengembangan usaha.

Lembaga UPK melalui kelompok Simpan Pinjam Perempuan diharapkan tetap ada dan menjadi salah satu dari Lembaga Kredit Mikro Informal (LKM) yang dapat terus diakses dan dimanfaatkan oleh masyarakat miskin, khususnya perempuan paska program. Berdasarkan uraian tersebut diatas, maka keberlanjutan UPK-SPP sangat diperlukan untuk mendukung penanggulangan kemiskinan. Penilaian kinerja keuangan UPK SPP menjadi penting dianalisis untuk mengetahui kemampuan UPK-SPP dapat lestari sebagai penyedia layanan keuangan bagi perempuan miskin. Analisis kinerja keuangan dengan indikator rasio likuiditas (Current Ratio/CR), rasio solvabilitas (Debt to Assets Ratio/DAR dan Primary Ratio/PR), serta analisa kinerja sosial (Jumlah Peminjam) dapat menjadi indikasi perkembangan dan keberlanjutan UPK-SPP di Lampung Selatan.

Menurut Tunggal (1995) jika perusahaan memutuskan menetapkan modal kerja dalam jumlah yang besar, kemungkinan tingkat likuiditas akan terjaga namun kesempatan untuk memperoleh laba yang besar akan menurun yang pada akhirnya berdampak pada menurunnya profitabilitas. Sebaliknya jika ingin memaksimalkan profitabilitas, kemungkinan dapat mempengaruhi tingkat likuiditas perusahaan. Makin tinggi likuiditas, terdapat kemungkinan yang lebih besar bahwa perusahaan akan dapat membayar kewajibannya tepat pada waktunya. Di lain pihak, likuiditas yang tinggi tak selalu menguntungkan karena berpeluang menimbulkan dana-dana yang menganggur yang sebenarnya dapat digunakan untuk berinvestasi untuk menguntungkan perusahaan. Sehingga untuk mengetahui tingkat likuiditas serta seberapa besar modal kerja yang 
dialokasikan perusahaan untuk operasi perusahaan, dapat digunakan rasio lancar atau yang lebih dikenal dengan Current Ratio (CR).

Pembiayaan dengan utang atau leverage atau solvabilitas keuangan menurut Brigham dan Houston (2006) dapat dilakukan jika investasi oleh pemegang saham tidak mencukupi sehingga perusahaan dapat tetap beroperasi dengan cara berhutang. Jika perusahaan memperoleh pengembalian yang lebih besar atas investasi yang dibiayai dengan dana pinjaman dibanding pembayaran bunga, maka pengembalian atas modal pemilik akan lebih besar. Sementara itu Sawir (2001) menyebutkan bahwa leverage atau solvabilitas dapat digunakan untuk meningkatkan hasil pengembalian pemegang saham, tetapi dengan risiko akan meningkatkan kerugian pada masa-masa suram. Perusahaan yang menggunakan lebih banyak hutang dibanding modal sendiri maka tingkat solvabilitas akan menurun karena beban bunga yang harus di tanggung juga meningkat.

Kinerja UPK SPP yang baik diukur dari laba (tingkat profitabilitas). Menurut Bambang Riyanto (1995), Return on Asset (ROA) merefleksikan seberapa banyak perusahaan telah memperoleh hasil atas seluruh sumber daya keuangan yang ditanamkan pada perusahaan. Ratio ROA sering digunakan oleh top manajemen untuk mengevaluasi unit-unit usaha dalam perusahaan yang multidivisional. Berdasarkan uraian tersebut, permasalahan penelitian ini adalah bagaimana kinerja keuangan dan kinerja sosial UPK SPP yang dapat mendukung keberlanjutan UPK Simpan Pinjam Perempuan sebagai LKM yang menyediakan layanan keuangan bagi perempuan di Lampung Selatan.

\section{METODE PENELITIAN}

Penelitian ini dilaksanakan pada 10 UPK SPP kecamatan di Kabupaten Lampung Selatan, yaitu kecamatan Natar, Jati Agung, Tanjung Bintang, Palas, Merbau Mataram, Sidomulyo, Kalianda, Raja Basa, Way Sulan dan Tanjung Sari pada tahun 2016. Metode yang digunakan dalam penelitian ini adalah metode sampel purposive (Purposive Sampling) dengan kriteria UPK SPP yang telah berdiri sejak tahun 2011 sampai 2015 dan telah menerbitkan laporan keuangan dengan lengkap berupa laporan neraca dan laporan laba rugi serta laporan jumlah peminjam. Penelitian ini menggunakan data data panel dari tahun 2011 sampai dengan tahun 2015 adalah data Laporan Keuangan (neraca keuangan dan laporan rugi/laba) serta data sekunder lainnya yang masih ada kaitannya 
dengan tujuan penelitian ini. Data primer penelitian ini diperoleh dari wawancara kepada pengelola Unit Pengelola Kegiatan Simpan Pinjam Perempuan.

Analisis data penelitian ini adalah analisis regresi berganda dengan persamaan kuadrat terkecil (OLS). Adapun model dasar penentuan ROA dengan persamaan sebagai berikut :



Dalam penelitian ini variabel independen yang diamati adalah sebagai berikut :

1. Analisa rasio keuangan

a. Rasio Likuiditas yang terdiri dari:

\begin{tabular}{|l|l|l|}
\hline Current Ratio $(\mathrm{CR})$ & $=$ & Aktiva_Lancar \\
\cline { 3 - 3 } & & Hutang Lancar \\
\hline
\end{tabular}

b. Rasio Solvabilitas yang terdiri dari :

\begin{tabular}{|c|c|c|}
\hline \multirow{2}{*}{$\begin{array}{c}\text { Debt to Assets Ratio } \\
\text { (DAR) }\end{array}$} & \multirow{2}{*}{$=$} & Total Hutang \\
\hline & & Total Aktiva \\
\hline \multirow{2}{*}{ Primary Ratio (PR) } & \multirow{2}{*}{$=$} & Total Modal \\
\hline & & Total Aktiva \\
\hline
\end{tabular}

2. Analisa Kinerja Sosial

Jangkauan Peminjam

Untuk jangkauan peminjam dihitung dari jumlah peminjam (JP) yang dalam UPK SPP ini yang merupakan jumlah kelompok.

Variabel dependen yang digunakan dalam penelitian ini adalah sebagai berikut :

a. Rasio Profitabilitas yang terdiri dari :

\begin{tabular}{|c|l|l|}
\hline $\begin{array}{c}\text { Return } \text { on Asset } \\
(\text { ROA })\end{array}$ & $=$ & Laba Bersih \\
\hline & Jumlah Aktiva \\
\hline
\end{tabular}




\section{HASIL DAN PEMBAHASAN}

\section{Kinerja Keuangan Unit Pengelola Kegiatan Simpan Pinjam Perempuan}

Kinerja Current Ratio (CR)

Current Ratio (CR) yang diperoleh sepanjang kurun waktu 2011-2015 dengan CR paling tinggi terjadi pada tahun 2014 yaitu sebesar 3.659.322.587,68 dan CR paling rendah terjadi pada tahun 2013 yaitu sebesar 164,96. Jika dilihat dari keseluruhan hasil CR menunjukkan persentase lebih dari $150 \%$ melebihi batas aman dalam penilaian likuiditas (Kasmir, 2016). Nilai CR yang tinggi diakibatkan karena UPK SPP memiliki utang lancar yang sangat kecil bahkan pada tahun 2014 dan 2015 sebagian besar dari UPK SPP memiliki utang 0.

Rata-rata nilai CR yang melebihi $150 \%$ menunjukkan bahwa UPK SPP memiliki kemampuan dalam memenuhi kewajiban jangka pendek/utang lancar dengan asumsi bahwa semua aktiva lancar dikonversikan kedalam kas. Hal ini menunjukkan UPK SPP sangat likuid. Selain itu, hasil nilai rasio juga menunjukkan UPK SPP memiliki kelebihan dana dalam bentuk aktiva lancar yang sangat berlimpah yang tidak digunakan untuk pencapaian laba. Jika UPK SPP memanfaatkan aktiva lancarnya untuk disalurkan sebagai pinjaman kepada peminjam maka akan diperoleh keuntungan yang lebih besar.

Tabel 1. Kinerja Current Ratio (CR) UPK SPP Lampung Selatan

\begin{tabular}{lrrrrr}
\hline \multirow{2}{*}{ Lokasi UPK } & \multicolumn{5}{c}{ Current Ratio $(\boldsymbol{C R})$} \\
\cline { 2 - 6 } & $\mathbf{2 0 1 1}$ & $\mathbf{2 0 1 2}$ & $\mathbf{2 0 1 3}$ & $\mathbf{2 0 1 4}$ & \multicolumn{2}{c}{$\mathbf{2 0 1 5}$} \\
\hline Natar & 117,44 & 516,03 & 577,84 & $1.079,39$ & $1.250,95$ \\
\hline Jati Agung & 92,04 & 56,97 & 34,90 & $5.757 .179 .564,60$ & $34.176,75$ \\
\hline Tanjung Bintang & 241,25 & 139,61 & 251,51 & 130,37 & 140,75 \\
\hline Palas & 80,57 & 63,05 & 69,69 & $3.764 .394 .240,00$ & $3.938 .027 .559,00$ \\
\hline Merbau Mataram & 170,57 & 274,06 & 194,99 & $3.780 .185 .134,00$ & $3.845 .036 .610,31$ \\
\hline Sidomulyo & 250,52 & 46,44 & 334,42 & $6.558 .319 .441,00$ & $6.459 .266 .520,00$ \\
\hline Kalianda & $1.070,68$ & 234,50 & 23,60 & $3.554 .612 .623,00$ & $18.184,68$ \\
\hline Raja Basa & 127,03 & 36,42 & 35,31 & $4.779 .239 .542,00$ & $4.473 .461 .690,00$ \\
\hline Way Sulan & 537,73 & 130,66 & 100,72 & $3.637 .006 .800,00$ & 27,92 \\
\hline Tanjung Sari & 199,36 & 53,09 & 26,66 & $4.762 .287 .322,47$ & $5.283 .700 .851,98$ \\
\hline \multicolumn{1}{c}{ Min } & $\mathbf{8 0 , 5 7}$ & $\mathbf{3 6 , 4 2}$ & $\mathbf{2 3 , 6 0}$ & & $\mathbf{1 3 0 , 3 7}$ \\
\hline Max & $\mathbf{1 . 0 7 0 , 6 8}$ & $\mathbf{5 1 6 , 0 3}$ & $\mathbf{5 7 7 , 8 4}$ & $\mathbf{6 . 5 5 8 . 3 1 9 . 4 4 1 , 0 0}$ & $\mathbf{6 . 4 5 9 . 2 6 6 . 5 2 0 , 0 0}$ \\
\hline Rata-Rata & $\mathbf{2 8 8 , 7 2}$ & $\mathbf{1 5 5 , 0 8}$ & $\mathbf{1 6 4 , 9 6}$ & $\mathbf{3 . 6 5 9 . 3 2 2 . 5 8 7 , 6 8}$ & $\mathbf{2 . 3 9 9 . 9 5 4 . 7 0 1 , 2 3}$ \\
\hline
\end{tabular}

\section{Kinerja Debt to Assets Ratio (DAR)}

Debt to Assets Ratio (DAR) yang diperoleh berdasarkan kurun waktu 2011-2015 diperoleh rata-rata nilai rasio paling tinggi pada tahun 2013 yaitu sebesar 0,017 dan paling 186 | Analisis Faktor-Faktor Yang Mempengaruhi Profitabilitas Unit Pengelola Kegiatan Simpan Pinjam Perempuan (UPK SPP) Di Lampung Selatan 
rendah terjadi pada tahun 2014 yaitu sebesar 0,001. Jika dilihat dari nilai rata-rata rasio DAR yang paling tinggi 0,017 atau 1,7\% menunjukkan bahwa hanya $1.7 \%$ saja aktiva yang ada di UPK SPP yang dibiayai oleh utang. Hasil perhitungan dari rasio DAR menunjukkan bahwa sebagian besar dari UPK SPP hanya memiliki utang yang sangat kecil dalam pembiayaan aktivanya. Hal ini disebabkan karena UPK SPP memperoleh aktivanya yang merupakan bantuan langsung masyarakat dan dana bergulir yang tidak mengharuskan pengembalian kepada pemerintah dan hanya utang kepada kelembagaan UPK dan kelompok serta dana sosial orang miskin bukan merupakan utang yang harus dikembalikan dengan bunga pinjaman tertentu.

Tabel 2 Kinerja Debt to Assets Ratio (DAR) UPK SPP Lampung Selatan

\begin{tabular}{lccccc}
\hline \multirow{2}{*}{ Lokasi UPK } & \multicolumn{5}{c}{ Debt to Assets Ratio (DAR) } \\
\cline { 2 - 6 } Natar & $\mathbf{2 0 1 1}$ & $\mathbf{2 0 1 2}$ & $\mathbf{2 0 1 3}$ & $\mathbf{2 0 1 4}$ & $\mathbf{2 0 1 5}$ \\
\hline Jati Agung & 0,008 & 0,002 & 0,002 & 0,001 & 0,002 \\
\hline Tanjung Bintang & 0,011 & 0,017 & 0,028 & 0,000 & 0,000 \\
\hline Palas & 0,004 & 0,007 & 0,004 & 0,007 & 0,007 \\
\hline Merbau Mataram & 0,012 & 0,015 & 0,014 & 0,000 & 0,000 \\
\hline Sidomulyo & 0,006 & 0,003 & 0,005 & 0,000 & 0,000 \\
\hline Kalianda & 0,004 & 0,020 & 0,003 & 0,000 & 0,000 \\
\hline Raja Basa & 0,001 & 0,004 & 0,040 & 0,000 & 0,000 \\
\hline Way Sulan & 0,008 & 0,027 & 0,028 & 0,000 & 0,000 \\
\hline Tanjung Sari & 0,002 & 0,008 & 0,010 & 0,000 & 0,034 \\
\hline Min & 0,005 & 0,018 & 0,036 & 0,000 & 0,000 \\
\hline Max & $\mathbf{0 , 0 0 1}$ & $\mathbf{0 , 0 0 2}$ & $\mathbf{0 , 0 0 2}$ & $\mathbf{0 , 0 0 0}$ & $\mathbf{0 , 0 0 0}$ \\
\hline Rata-rata & $\mathbf{0 , 0 1 2}$ & $\mathbf{0 , 0 2 7}$ & $\mathbf{0 , 0 4 0}$ & $\mathbf{0 , 0 0 7}$ & $\mathbf{0 , 0 3 4}$ \\
\hline
\end{tabular}

Kinerja Primary Ratio (PR)

Kinerja dari Primary Ratio (PR) dapat dilihat dari Tabel 3 berikut ini.

Tabel 3 Kinerja Variabel Primary Ratio (PR)

\begin{tabular}{llllll}
\hline \multirow{2}{*}{ Lokasi UPK } & \multicolumn{5}{c}{ Primary Ratio (PR) } \\
\cline { 2 - 6 } Natar & 2011 & 2012 & 2013 & 2014 & 2015 \\
\hline Jati Agung & 0,99 & 1,00 & 1,00 & 1,00 & 2,14 \\
\hline Tanjung Bintang & 0,99 & 0,98 & 0,97 & 1,00 & 1,00 \\
\hline Palas & 1,00 & 0,99 & 1,00 & 0,99 & 0,99 \\
\hline Merbau Mataram & 0,99 & 0,98 & 0,99 & 1,00 & 1,00 \\
\hline Sidomulyo & 1,00 & 0,97 & 1,00 & 1,00 & 1,00 \\
\hline Kalianda & 1,00 & 0,98 & 1,00 & 1,00 & 1,06 \\
\hline Raja Basa & 0,99 & 0,97 & 0,96 & 1,00 & 1,00 \\
\hline Way Sulan & 1,00 & 0,99 & 0,97 & 1,00 & 1,00 \\
\hline
\end{tabular}

187 | Analisis Faktor-Faktor Yang Mempengaruhi Profitabilitas Unit Pengelola Kegiatan Simpan Pinjam Perempuan (UPK SPP) Di Lampung Selatan 


\begin{tabular}{llllll}
\hline Tanjung Sari & 1,00 & 0,98 & 0,96 & 1,00 & 1,00 \\
\hline Min & 0,99 & 0,97 & 0,96 & 0,99 & 0,97 \\
\hline Max & 1,00 & 1,00 & 1,00 & 1,00 & 2,14 \\
\hline Rata-rata & 0,99 & 0,98 & 0,98 & 1,00 & 1,12 \\
\hline
\end{tabular}

Primary Ratio (PR) yang diperoleh sepanjang kurun waktu 2011-2015 dengan rata-rata PR tertinggi terjadi pada tahun 2015 yaitu mencapai 1,12 dan paling rendah yaitu pada tahun 2012 dan 2013 yaitu 0,98. Berdasarkan Surat Edaran Bank Indonesia No. 6/10/PBI/2004 Tahun 12 April 2004 nilai standar tingkat kesehatan Bank Indonesia untuk PR sebesar $8 \%$. Hasil dari perhitungan rasio PR UPK SPP melebihi dari $8 \%$ bahkan ada yang memiliki rasio 1 atau 100\% yang menunjukkan seluruh modal yang digunakan dapat digunakan untuk menyangga aktiva jika terjadi kerugian.

Kinerja Return on Assets (ROA)

Return on Assets (ROA) dalam kurun waktu 2011-2015 menunjukkan adanya peningkatan setiap tahunnya. Rata-rata rasio ROA paling tinggi terjadi pada tahun 2015 yaitu sebesar 0,37 dan paling rendah terjadi pada tahun 2011 yaitu sebesar 0,16 . Nilainya yang semakin meningkat setiap tahunnya pada UPK SPP di wilayah Lampung Selatan ini, menunjukkan kinerja UPK SPP yang mampu mengelola asetnya secara efektif untuk menghasilkan laba. Jika dilihat dari nilai rata-rata ROA maka menurut Surat Edaran Bank Indonesia No. 6/23 DPNP Tahun 2004 semua UPK SPP termasuk dalam kategori Sangat Sehat karena memiliki nilai ROA $>1,5 \%$.

Tabel 4. Kinerja Return on Assets (ROA)

\begin{tabular}{lccccc}
\hline \multirow{2}{*}{ Lokasi UPK } & \multicolumn{5}{c}{ Rasio Pengembalian Aset (Return on Assets/ROA) } \\
\cline { 2 - 5 } & $\mathbf{2 0 1 1}$ & $\mathbf{2 0 1 2}$ & $\mathbf{2 0 1 3}$ & $\mathbf{2 0 1 4}$ & $\mathbf{2 0 1 5}$ \\
\hline Natar & 0,22 & 0,22 & 0,27 & 1,00 & 1,00 \\
\hline Jati Agung & 0,12 & 0,17 & 0,15 & 0,09 & 0,08 \\
\hline Tanjung Bintang & 0,29 & 0,36 & 0,46 & 0,57 & 0,68 \\
\hline Palas & 0,09 & 0,12 & 0,16 & 0,15 & 0,16 \\
\hline Merbau Mataram & 0,20 & 0,27 & 0,40 & 0,50 & 0,58 \\
\hline Sidomulyo & 0,31 & 0,39 & 0,50 & 0,11 & 0,65 \\
\hline Kalianda & 0,11 & 0,16 & 0,15 & 0,16 & 0,16 \\
\hline Raja Basa & 0,14 & 0,15 & 0,18 & 0,17 & 0,16 \\
\hline Way Sulan & 0,05 & 0,06 & 0,06 & 0,09 & 0,11 \\
\hline Tanjung Sari & 0,12 & 0,12 & 0,15 & 0,17 & 0,17 \\
\hline Min & $\mathbf{0 , 0 5}$ & $\mathbf{0 , 0 6}$ & $\mathbf{0 , 0 6}$ & $\mathbf{0 , 0 9}$ & $\mathbf{0 , 0 8}$ \\
\hline Max & $\mathbf{0 , 3 1}$ & $\mathbf{0 , 3 9}$ & $\mathbf{0 , 5 0}$ & $\mathbf{1 , 0 0}$ & $\mathbf{1 , 0 0}$ \\
\hline Rata-rata & $\mathbf{0 , 1 6}$ & $\mathbf{0 , 2 0}$ & $\mathbf{0 , 2 5}$ & $\mathbf{0 , 3 0}$ & $\mathbf{0 , 3 7}$ \\
\hline
\end{tabular}

\section{Kinerja Sosial}

Jangkauan Peminjam

Tabel 5. Kinerja Jumlah Peminjam (JP)

188 | Analisis Faktor-Faktor Yang Mempengaruhi Profitabilitas Unit Pengelola Kegiatan Simpan Pinjam Perempuan (UPK SPP) Di Lampung Selatan 


\begin{tabular}{lccccc}
\hline \multirow{2}{*}{ Lokasi UPK } & \multicolumn{5}{c}{ Jumlah Peminjam } \\
\cline { 2 - 6 } & $\mathbf{2 0 1 1}$ & $\mathbf{2 0 1 2}$ & $\mathbf{2 0 1 3}$ & $\mathbf{2 0 1 4}$ & $\mathbf{2 0 1 5}$ \\
\hline Natar & 233 & 289 & 278 & 422 & 489 \\
\hline Jati Agung & 247 & 256 & 290 & 278 & 283 \\
\hline Tanjung Bintang & 287 & 277 & 364 & 431 & 323 \\
\hline Palas & 75 & 160 & 160 & 160 & 183 \\
\hline Merbau Mataram & 178 & 161 & 207 & 202 & 160 \\
\hline Sidomulyo & 230 & 256 & 246 & 286 & 403 \\
\hline Kalianda & 149 & 221 & 210 & 235 & 239 \\
\hline Raja Basa & 191 & 182 & 214 & 205 & 205 \\
\hline Way Sulan & 127 & 119 & 120 & 115 & 117 \\
\hline Tanjung Sari & 196 & 191 & 255 & 311 & 361 \\
\hline Total & $\mathbf{1 . 9 1 3}$ & $\mathbf{2 . 1 1 2}$ & $\mathbf{2 . 3 4 4}$ & $\mathbf{2 . 6 4 5}$ & $\mathbf{2 . 7 6 3}$ \\
\hline Min & $\mathbf{7 5}$ & $\mathbf{1 1 9}$ & $\mathbf{1 2 0}$ & $\mathbf{1 1 5}$ & $\mathbf{1 1 7}$ \\
\hline Max & $\mathbf{2 8 7}$ & $\mathbf{2 8 9}$ & $\mathbf{3 6 4}$ & $\mathbf{4 3 1}$ & $\mathbf{4 8 9}$ \\
\hline Rata-rata & $\mathbf{1 9 1}$ & $\mathbf{2 1 1}$ & $\mathbf{2 3 4}$ & $\mathbf{2 6 5}$ & $\mathbf{2 7 6}$ \\
\hline
\end{tabular}

Kinerja Jumlah Peminjam pada kurun waktu 2011-2015 menunjukkan adanya peningkatan jumlah peminjam (JP) setiap tahunnya. Jumlah peminjam paling tinggi terjadi pada tahun 2015 yaitu sebanyak 276 orang yang meningkat sebanyak 11 orang dari tahun sebelumnya. Hal ini menunjukkan UPK SPP memiliki kinerja yang terus meningkat dalam hal meningkatkan jumlah peminjam. UPK Natar merupakan UPK yang memiliki jumlah peminjam paling banyak yaitu jika ditotal dalam lima tahun tersebut terdapat 1.711 peminjam sedangkan UPK Palas dengan jumlah peminjam paling sedikit yaitu jika ditotal dalam lima tahun tersebut terdapat 598 peminjam.

\section{Analisis Faktor-Faktor yang Mempengaruhi Profitabilitas UPK SPP}

\section{Uji Asumsi Klasik}

\section{Uji Normalitas}

Uji normalitas dilakukan dengan uji Jarque-Bera (JB) dan diperoleh hasil pada tabel 2.

Tabel 2. Hasil Uji Normalitas

\begin{tabular}{ccc}
\hline Nilai & Jarque-Bera & Signifikansi \\
\hline Residual & 2,446 & 0,2942 \\
\hline
\end{tabular}

Berdasarkan hasil estimasi dengan uji JB-test ditemukan bahwa besarnya nilai Jargue Bera normality test statistics adalah 2,446. Kemudian dibandingkan dengan nilai $\chi^{2}$ tabel $(0,05)$ degree of freedom (derajat kebebasan) $=2$ maka diperoleh nilai 9,48773 (JB-test $=2,446<\chi^{2}$ tabel $=9,48773$ ). Maka faktor penganggu atau residual berdistribusi normal pada tingkat kepercayaan 95 persen. Dari hasil estimasi juga diperoleh nilai 
probabilitas yaitu 0,2942 sehingga nilai signifikansi lebih besar dari 0,05. Hal ini menunjukkan bahwa data yang digunakan dalam penelitian ini berdistribusi normal.

\section{Uji Multikolinearitas}

Uji multikolinearitas dilakukan dengan melihat Centered VIF (Variance Inflation Factor) dengan nilai VIF tidak lebih dari 10. Hasil uji multikolinieritas menunjukkan bahwa variabel independen (CR, DAR, PR, dan JP) memiliki nilai Centered VIF dibawah 10 sehingga dapat dikatakan tidak ada hubungan yang tinggi antar variabel independen.

Tabel 7. Hasil Uji Multikolinearitas

\begin{tabular}{cccc}
\hline \hline Variable & $\begin{array}{c}\text { Coefficient } \\
\text { Variance }\end{array}$ & $\begin{array}{c}\text { Uncentered } \\
\text { VIF }\end{array}$ & $\begin{array}{c}\text { Centered } \\
\text { VIF }\end{array}$ \\
\hline \hline C & 0.025441 & 51.30812 & NA \\
CR & $1.28 \mathrm{E}-05$ & 3.893502 & 1.490381 \\
DAR & 7.093765 & 2.465606 & 1.548633 \\
PR & 0.023984 & 51.12670 & 1.259281 \\
JP & 0.000828 & 10.53130 & 1.267330 \\
\hline \hline
\end{tabular}

\section{Uji Autokorelasi}

Uji autokorelasi dalam penelitian ini menggunakan uji Breusch-Godfrey Serial Correlation LM-Test dimana tidak ada autokorelasi jika nilai signifikansi dari Obs*RSquared lebih besar dari 0,05.

Tabel 8. Hasil Estimasi LM-Test

\begin{tabular}{llll}
\hline \hline F-statistic & 0.428292 & Prob. F(2,43) & 0.6544 \\
Obs*R-squared & 0.976574 & Prob. Chi-Square(2) & 0.6137 \\
\hline \hline
\end{tabular}

Hasil uji autokorelasi menunjukkan nilai signifikansi Obs*Rsquared yaitu 0,6137 lebih besar dari 0,05 sehingga tidak terdapat autokorelasi. Oleh karena itu, model regresi ini tidak terdapat korelasi antara kesalahan pengganggu pada periode tertentu dengan kesalahan pengganggu pada periode sebelumnya.

\section{Uji Heteroskedastitas}

Uji heteroskedastitas dalam penelitian ini menggunakan uji Breusch-PaganGodfrey dimana tidak ada heteroskedastitas jika nilai signifikansi yang ditunjukkan dengan nilai Prob. chi square (2) pada Obs*R-squared lebih besar dari 0,05. Hasil uji heteroskedastitas diperoleh nilai signifikansi Obs*R-squared yaitu 0,0961 sehingga nilainya lebih besar dari 0,05 . Hal ini menunjukkan bahwa model regresi tidak mengandung gejala heteroskedastisitas.

Tabel 9. Nilai Breusch-Pagan-Godfrey 


\begin{tabular}{llll}
\hline \hline F-statistic & 2.104738 & Prob. F(4,45) & 0.0959 \\
Obs*R-squared & 7.880119 & Prob. Chi-Square(4) & 0.0961 \\
Scaled explained SS & 12.07336 & Prob. Chi-Square(4) & 0.0168 \\
\hline \hline
\end{tabular}

\section{Analisis Faktor-Faktor yang mempengaruhi ROA}

Untuk menganalisis faktor-faktor yang mempengaruhi ROA dilakukan dengan analisis regresi berganda. Dalam analisis regresi berganda terdapat 3 analisis yaitu koefisien determinasi (R Square), uji simultan (uji F), dan uji parsial (uji t). Hasil analisis regresi untuk mengetahui faktor-faktor yang mempengaruhi ROA disajikan pada tabel 5.6 .

Tabel 10. Analisis Regresi

\begin{tabular}{lrcrr}
\hline \hline \multicolumn{1}{c}{ Variable } & Coefficient & Std. Error & t-Statistic & Prob. \\
\hline \hline C & -0.330031 & 0.159503 & -2.069124 & 0.0443 \\
CR & -0.004040 & 0.003581 & -1.128127 & 0.2652 \\
DAR & -3.494214 & 2.663412 & -1.311931 & 0.1962 \\
PR & 0.321622 & 0.154869 & 2.076738 & 0.0436 \\
JP & 0.139465 & 0.028775 & 4.846821 & 0.0000 \\
\hline \hline R-squared & 0.535851 & Mean dependent var & 0.258110 \\
Adjusted R-squared & 0.494593 & S.D. dependent var & 0.221482 \\
S.E. of regression & 0.157456 & Akaike info criterion & -0.764699 \\
Sum squared resid & 1.115661 & Schwarz criterion & -0.573496 \\
Log likelihood & 24.11746 & Hannan-Quinn criter. & -0.691888 \\
F-statistic & 12.98789 & Durbin-Watson stat & 2.095754 \\
Prob(F-statistic) & 0.000000 & &
\end{tabular}

Model regresi yang diperoleh berdasarkan perhitungan regresi dapat dilihat sebagai berikut :

$$
\text { ROA = -0,330 - 0,004 CR - 3,494 DAR + 0,321 PR + 0,139 JP }
$$

Dari hasil regresi linear berganda diatas ada beberapa hal yang dijelaskan beberapa hal berikut :

1. Hanya variabel independen JP berpengaruh secara signifikan terhadap variabel dependen ROA karena tingkat signifikansi sebesar 0,000 lebih kecil dari tingkat signifikansi sebesar 0,05 sedangkan variabel independen CR, DAR,dan PR dan tidak berpengaruh secara signifikan karena tingkat signifikansinya 0,2652;0,1962 dan 0,0436 lebih besar dari 0,05.

2. Nilai koefisien regresi JP (X4) sebesar 0,139 memiliki pengertian bahwa setiap kenaikan 1 satuan dari JP maka akan memberikan pengaruh kenaikan terhadap ROA (Y) sebesar 0,139 satuan.

191 Analisis Faktor-Faktor Yang Mempengaruhi Profitabilitas Unit Pengelola Kegiatan Simpan Pinjam Perempuan (UPK SPP) Di Lampung Selatan 


\section{Koefisien Determinasi (R square)}

Hasil koefisien determinasi diatas yaitu 0,538 sehingga dapat dikatakan variabel independen secara bersama-sama mampu mempengaruhi ROA sebesar 53,58\% sedangkan sisanya yaitu 46,42\% dipengaruhi oleh variabel lain yang tidak menjadi fokus dalam penelitian ini.

\section{Uji Simultan (Uji F)}

Uji Simultan pada penelitian ini menunjukkan F hitung yaitu 12,987 lebih besar dari F-tabel yaitu 5,19 dengan nilai signifikansi 0,000 lebih kecil dari 0,05. Dari hasil ini dapat diambil kesimpulan bahwa terdapat pengaruh simultan dari variabel Current Ratio (CR), Debt to Assets Ratio (DAR), Primary Ratio (PR), dan Jumlah Peminjam (JP) terhadap Return on Assets (ROA).

\section{Uji Statistik t (Uji t)}

Hasil uji statistik t pada penelitian ini sebagai berikut :

1. Variabel CR memiliki nilai t hitung -1,128 yang lebih kecil dari t tabel 2,571 dan nilai signifikansi 0,265 lebih besar dari 0,05 , yang membuktikan tidak terdapat pengaruh secara parsial yang signifikan dari variabel CR terhadap ROA.

2. Variabel DAR memiliki nilai t hitung -1,311 yang lebih kecil dari t tabel 2,571 dan signifikansi 0,196 sehingga nilai signifikansi lebih besar dari 0,05, yang membuktikan tidak terdapat pengaruh secara parsial yang signifikan dari variabel DAR terhadap ROA.

3. Variabel PR memiliki nilai t hitung 2,076 yang lebih kecil dari t tabel 2,571 dan nilai signifikansi 0,043 lebih kecil dari 0,05, yang membuktikan tidak terdapat pengaruh secara parsial yang signifikan dari variabel PR terhadap. ROA.

4. Variabel JP memiliki nilai $t$ hitung 4,846 yang lebih besar dari t tabel 2,571 dan nilai signifikansi 0,000 lebih kecil dari 0,05, yang membuktikan terdapat pengaruh secara parsial yang signifikan dari variabel jumlah peminjam terhadap ROA.

\section{Hubungan Current Ratio (CR) terhadap Return on Assets (ROA)}

Dari hasil uji statistik t menunjukkan tidak terdapat pengaruh secara parsial yang signifikan dari variabel Current Ratio (CR) terhadap Return on Assets (ROA) karena memiliki nilai thitung -1,128 dan nilai signifikansi CR 0,265 lebih besar dari 0,05. Hasil ini menunjukkan bahwa tinggi atau rendahnya nilai rasio ini tidak akan mempengaruhi tingkat profitabilitas pada UPK SPP tersebut. Rasio CR pada UPK SPP di Kabupaten 
Lampung Selatan tidak mempunyai pengaruh terhadap profitabilitas kemungkinan disebabkan karena sejak tahun 2014-2015 tidak memiliki utang lagi sehingga tidak dapat digunakan sebagai pembanding antara satu UPK dengan UPK yang lain. Dengan demikian hipotesis pertama yang menyatakan bahwa rasio CR dapat membedakan status tingkat kinerja berdasarkan ROA tidak dapat diterima.

Penelitian ini tidak sama dengan penelitian yang dilakukan oleh Mahardhika dan Marbun (2016) yang menunjukkan bahwa terdapat pengaruh signifikan positif antara variabel Current Ratio (CR) terhadap Return on Assets (ROA). Pada penelitian tersebut menyatakan jika Current Ratio (CR) meningkat maka Return on Assets (ROA) juga akan meningkat pada perusahaan perbankan dengan nilai kapitalisasi yang besar. CR yang meningkat maka ROA juga akan meningkat karena kemampuan dari perusahaan untuk menutupi utang mengurangi beban tambahan atas kewajibannya dan jumlah utang lancarnya berkurang.

\section{Hubungan Debt to Assets Ratio (DAR) terhadap Return on Assets (ROA)}

Berdasarkan hasil uji statistik t menunjukkan tidak terdapat pengaruh secara parsial yang signifikan dari variabel Debt to Assets Ratio (DAR) terhadap Return on Assets (ROA). Hal ini dibuktikan variabel Debt to Assets Ratio (DAR) karena memiliki nilai t hitung -1,311 dan signifikansi 0,1962 yang lebih besar dari 0,05. Hasil ini menunjukkan bahwa tinggi atau rendahnya nilai rasio ini tidak akan mempengaruhi tingkat profitabilitas pada UPK SPP tersebut. Hal ini disebabkan karena sejak tahun 2014 - 2015 UPK SPP tidak memiliki utang sehingga tidak dapat digunakan sebagai pembanding untuk mengukur pengaruh DAR terhadap ROA. Dengan demikian hipotesis kedua yang menyatakan bahwa rasio DAR dapat membedakan status tingkat kinerja berdasarkan ROA tidak dapat diterima.

Penelitian ini sama dengan penelitian yang dilakukan Waqas Bin Khidmat dan Mobeen Ur Rehman (2014) pada perusahaan kimia yang memiliki modal yang besar sedangkan utangnya kecil yang menyatakan bahwa rasio solvabilitas bepengaruh negatif yang berarti jika rasio solvabilitas meningkat maka kinerja keuangan akan menurun. Namun tidak sama dengan penelitian yang dilaksanakan di UPK SPP yang menyatakan bahwa rasio solvabilitas berpengaruh secara signifikan terhadap ROA karena utang pada UPK SPP pada tahun 2014-2015 sangat kecil bahkan ada UPK SPP tidak memiliki utang lagi pada akhir tahun. 


\section{Hubungan Primary Ratio (PR) terhadap Return on Assets (ROA)}

Berdasarkan hasil uji statistik t menunjukkan pengaruh secara parsial yang signifikan dari variabel Primary Ratio (PR) terhadap Return on Assets (ROA). Hasil ini menunjukkan variabel Primary Ratio (PR) memiliki nilai thitung 2,076 dan signifikansi 0,0436. Selain itu variabel Primary Ratio $(P R)$ memiliki pengaruh positif dengan Return on Assets (ROA) yang berbeda dengan teori yang menyatakan bahwa rasio solvabilitas berpengaruh negatif terhadap profitabilitas. Pada UPK SPP hampir semua modal juga merupakan aktiva, sehingga rasio hampir mendekati 1 yang berarti modal dan aktiva memiliki nilai yang hampir sama. Seharusnya semakin tinggi rasio solvabilitas maka kinerja keuangan akan menurun. Dengan demikian hipotesis ketiga yang menyatakan bahwa rasio PR dapat membedakan status tingkat kinerja berdasarkan ROA tidak dapat diterima.

\section{Hubungan Jumlah Peminjam (JP) terhadap Return on Assets (ROA)}

Berdasarkan hasil uji statistik $\mathrm{t}$ menunjukkan pengaruh secara parsial yang signifikan dari variabel Jumlah Peminjam (JP) terhadap Return on Assets (ROA). Hal ini dibuktikan dengan variabel jumlah peminjam memiliki nilai t hitung 4,846 dan signifikansi 0,000 yang lebih kecil dari 0,05. Selain itu variabel jumlah peminjam memiliki pengaruh positif dengan Return on Assets (ROA) yang artinya semakin tinggi nilai jumlah peminjam (JP) akan semakin tinggi pula Return on Assets (ROA). Nilai Return on Assets (ROA) akan meningkat sebesar 0,139 satuan setiap kenaikan satusatuan dari jumlah peminjam (JP). Dengan demikian hipotesis keempat yang menyatakan bahwa jumlah peminjam (JP) dapat membedakan status tingkat kinerja berdasarkan ROA dapat diterima.

\section{KESIMPULAN}

\section{Kesimpulan}

Dari hasil pembahasan yang telah disajikan, dapat disimpulkan sebagai berikut :

1. Variabel independen CR, DAR, PR, dan JP secara bersama-sama mampu mempengaruhi ROA sebesar 53,58 \% sedangkan sisanya yaitu 46,42\% dipengaruhi oleh variabel lain yang tidak menjadi fokus dalam penelitian ini;

2. Terdapat pengaruh simultan (secara bersama-sama) CR, DAR, PR, dan JP terhadap ROA. 
3. Tidak terdapat pengaruh secara parsial yang signifikan dari variabel independen $C R$, DAR, PR, kecuali variabel JP terhadap ROA.

4. Hanya variabel independen JP berpengaruh secara signifikan terhadap variabel dependen ROA

\section{DAFTAR PUSTAKA}

Agnes Sawir, 2009. Analisa Kinerja Keuangan dan Perencanaan Keuangan Perusahaan, PT. Gramedia Pustaka Utama, Jakarta

Arief Widjaja Tunggal, 1995, Dasar-Dasar Analisis Laporan Keuangan, PT.Rineka Cipta, Jakarta.

Arief Sugiono dan Edi Untung., 2016, Analisa Laporan Keuangan, PT. Grasindo, Jakarta.

Badan Pusat Statistik., 2017, Jumlah Penduduk Miskin Menurut Provinsi 2007-2017, https://www.bps.go.id/linkTableDinamis/view/id/ 1119 diakses tanggal 14 Februari 2018.

Bambang Riyanto, 2010, Dasar-Dasar Pembelanjaan Perusahaan, Edisi Keempat, BPFE, Yogyakarta

Brigham, Eugene F dan Houston, Joel F, 2013. Dasar-Dasar Manajemen Keuangan, Salemba Empat, Jakarta

Kasmir., 2016, Analisis Laporan Keuangan, Edisi Ketiga, Raja Grafindo Persada, Jakarta.

P.A Mahardika dan D.P Marbun, 2016, Pengaruh Current Ratio dan Debt to Equity Ratio terhadap Return on Assets, dalam Jurnal Widyakala, Vol.3, Maret 206, Universitas Pembangunan Jaya.

Sofyan Syafrie Harahap., 2009, Analisis Kritis Laporan Keuangan, cetakan ketiga, Edisi Pertama, Raja Grafindo Persada, Jakarta.

Toto Prihadi., 2013. Analisis Laporan Keuangan, Edisi Ketiga, PPM Manajemen, Jakarta.

World Bank, 2017, Total Populasi Indonesia, https://data.worldbank.org/country/ Indonesia, diakses tanggal 14 Februari 2018. 